Article

\title{
The Mediating Role of CSR on the Market Orientation and Strategic Performance Relationship-A Study of the Public Housing Companies in Sweden
}

\author{
Agneta Sundström (iD) and Zahra Ahmadi *(D) \\ Department of Business and Economics Studies, Faculty of Education and Business, University of Gävle, \\ SE-80176 Gävle, Sweden; awd@hig.se \\ * Correspondence: zaaahi@hig.se
}

Received: 20 January 2019; Accepted: 9 March 2019; Published: 13 March 2019

\begin{abstract}
This article serves to analyze the impact of corporate social responsibility (CSR) on (1) the market orientation and strategic performance relationship related to public housing companies' choice of construction strategies and (2) the companies' responsiveness to gathered and disseminated customer information. The quantitative method is applied, with data analyzed by the PROCESS analysis. The result is based on a survey sent to 289 public housing companies in Sweden. Previous research suggests a positive relationship between market orientation and strategic performance, which was not confirmed by this study. When testing the mediation effects of CSR on the market orientation and construction strategies relationship, these hypotheses were confirmed related to social and environmental dimensions-not economic ones. This study was limited to public housing companies, a sector that radically differs from the situation of companies in the open market. The study increases public housing companies' knowledge of CSR effects on the market orientation and strategic performance relationship. This result contributes useful information for companies implementing CSR in their activities. The study highlights the importance of integrating CSR into an organization's market orientation work and shows how CSR improves the companies' ability to meet customers' strategic needs.
\end{abstract}

Keywords: market orientation; mediating; CSR; strategic performance; public housing companies; construction strategies

\section{Introduction}

Market orientation (MO) research commonly relies on the principle that a positive relationship exists between companies' market orientation and business strategic performance [1-4]. This MO-strategic performance (MO/SP) interrelationship has been criticized for being difficult to define, measure, and evaluate, contributing to split results in research. One cause of ambiguity is that performance is a multidimensional construct that must be accurately defined in order to measure its relationship to $\mathrm{MO}$ [5]. A second mentioned cause is that different situational characteristics that influence the nature of the sample make measurement results difficult to evaluate and assert [5].

Besides measurement problems, management-related issues can make the MO/SP relationship difficult to determine. MO investigation is something of a "black box", but research underscores the value of a new, more comprehensive market agenda [6] (p. 354). Mitchell et al. stress that MO has conceptual shortcomings and needs to "be re-conceptualized as a more comprehensive management framework" [7] (p. 160); they suggest that a sustainable MO approach includes the use of market strategy, including social, environmental, and economic concerns and responsibilities, 
to manage and respond to market conditions. Customers today are more organized, informed, and demanding regarding company engagement in corporate social responsibility (CSR) issues, which require new business strategies and efforts to create mutual value [8]. The main challenge is to replace the traditional view of $\mathrm{MO}$, which is based on assimilating knowledge of customer needs related to products and services, with an updated research approach that includes relevant CSR issues related to contextual circumstances.

During recent decades, the impact of CSR on the effectiveness of MO has received significant interest in both practice and research [9]. Many companies invest heavily in implementing and integrating the CSR concept into different core activities [10,11], with the intention of improving their image and reputation [12] and/or to meet critical stakeholder demands on the market [13]. Plenty of studies have debated the CSR and business financial performance relationship [14-16]. Although doubts exist due to the voluntary definitional character of CSR, most researchers agree that if companies work seriously with the concept and in ways that meet customer demands, these commitments positively influence long-term business performance [8,17].

As CSR has become more integrated into business activities, its mediating impact on the MO/SP relationship has to be considered, this study argues. The CSR connection to MO is crucial, due to the concept's focus on company willingness to meet stakeholder demands. Yet research focusing on the mediating effects of CSR on the MO/SP relationship has been limited, with few exceptions. Fatma et al. have studied the mediating role of trust on the MO/SP relationship [9]. Kara et al. have paid attention to product and sales issues [18]; Luo and Bhattacharya have focused on the mediating effects of CSR on the relationship between customer satisfaction and market value [10]; and Brik et al. have studied the bundling effects of CSR on the MO/SP relationship [19]. So far, few studies have focused on how CSR affects the MO/SP relationship in a public housing market, with its historically close customer relationships and long tradition of taking responsibility for the customers' well-being. Most studies are based on CSR and MO as aggregated concepts. This study contributes to showing how different dimensions of CSR (social, environmental and economic) affect the companies' responsiveness and how they strategically work to meet customer needs.

This study focuses on the mediation role of CSR on the MO/SP relationship in the context of public housing companies (PHCs) in Sweden. Increased demands from the EU resulted in new legislation in 2011 that requires PHCs to be market-oriented and obtain a profit on their investments. Traditional customer responsibility is instead supposed to be met by the PHCs' CSR work.

The philosophy of MO argues that there is a relationship between a company's responsiveness to customer needs and strategic performance [20]. This paper calculates the effects of CSR on both of these variables, because research shows that while companies may indicate responsiveness by implementing parts of the concept in different activities, this may or may not affect long-term strategic value for the customers. The strategic performance analysis contributes to show how CSR influences the PHCs' long-term decisions to meet customer needs concerning living conditions via the chosen construction strategies: renovation, new construction, reconstruction, demolition, vacancy, selling, and buying.

This article has two purposes, (1) to analyze the impact of CSR on the MO/SP relationship related to public housing companies' choice of construction strategies and (2) to analyze CSR's impact on the PHCs' responsiveness to gathered and disseminated information (GDI) from the customers. The two measurements indicate whether PHCs' CSR commitments correspond to customers' more short-term $\mathrm{MO}$ needs or have a long-term impact on the MO/SP relationship.

\section{Research Context (Swedish Public Housing Companies)}

SABO is the Swedish Association of Public Housing Companies, owned by the municipalities in Sweden. The association's roughly 300 PHC members manage around 802,000 dwellings. Historically, many people in Sweden lived in crowded and poor housing conditions during the 1930s. Pressures grew for society to assume greater responsibility, and a Public Housing Inquiry was appointed. In 1945, during an acute housing shortage after the Second World War, a government decision ensured the 
municipalities would provide good housing for everyone through the PHCs. Day nurseries, libraries, and housing for older people were integrated into the PHC environment. Sweden was unique within Europe, as the PHCs not only included welfare for less fortunate members of society, but also increased the quality of life for everyone.

During a new acute shortage of housing in the 1960s, the government decided to fund and build more than 1 million homes across the country over ten years. This effort, referred to as the Million Homes Program, not only eased the housing situation, but also improved the housing standard. The program gave the tenants the possibility of co-determination, offered leisure activities for children, created safe environments, provided assistance for jobs, combated homelessness, developed new technologies to save energy, and promoted integration.

Today, more than 3 million of 10 million Swedes live in rental housing, more than half of those in PHCs. According to SABO, this housing offers freedom in living, good service, predictable accommodation expenses, and an opportunity to influence housing and its cost. The rents are set after negotiations between proprietor and tenant representatives usually affiliated with the Swedish Union of Tenants. The proprietor sees the negotiation as an effective way of handling rent increases for a large number of tenants. Negotiations revolve around two points: the utility value of the apartments and changes to the costs of dwellings and management. The utility value is based on how tenants generally value various characteristics such as apartment conditions, benefits, location, environment, and quality of property management, etc.

The pricing of housing in the rental market has been criticized for favoring PHCs in relation to the private market. A new law in 2011 requires the PHCs to be regulated according to new market demands to improve their competitiveness. Simultaneously, the Million Homes Program faces the need for extensive improvements, such as investments in energy efficiency. Return on invested capital has meant that although there is a shortage of housing, it is difficult for PHCs to build at a cost that ordinary people can afford. According to the new legislation, PHCs should combine their social responsibility with a business-like market orientation approach. Due to the new program, the PHCs are required to focus on five areas: (1) growth for municipalities and regions, (2) integration through diversity and freedom of choice, (3) social responsibility, (4) housing with high quality, and (5) sustainable development.

This study reflects the PHCs' responsiveness to the tenants' requirements in living and tests the CSR impact on MO constructs, and how these influence construction strategies (in this paper, shown by strategic performance measures). Renovation, new construction, reconstruction, and buying of houses are strategic construction initiatives that can contribute to improvements in dwellings based on the tenants' needs, while demolition, high vacancy rates, and selling are strategic choices that reflect their dissatisfaction. The sale of housing in particular has resulted in harsh debate, as many of the tenants lack the ability to buy their homes.

The PHCs' long tradition of taking responsibility for the tenants' accommodations is unique in the world and is based on the Swedish welfare model, which other countries are trying to follow. The PHC model has been particularly important for the weaker groups of customers who have difficulty finding alternative living arrangements [21,22]. The PHCs experience several challenges due to new legislation, increased need for renovation/maintenance, increased need for dwellings in growing housing markets, and weakened economic conditions [23] in declining markets. In summary, the Swedish PHC model is in an economic, environmental, and social transformation position that affects their responsiveness to market demands and their choice of building strategies for the tenants as customers.

\section{Literature Review and Hypotheses}

\subsection{Market Knowledge, Responsiveness, and Performance Relationship (MO/SP)}

In the last three decades, the research by Kohli and Jaworski and Narver and Slater has had a major influence on $\mathrm{MO}$ research, providing tools for analyzing market knowledge and its relationship 
to performance [2,4]. While Kohli and Jaworski [2,24] pay most of their attention to the development of market intelligence and its impact on company responsiveness, Narver and Slater emphasize the significance of developing cross-functional culture that meets and ideally exceeds customer needs [4]. MO companies "continuously create superior customer value by sharing the knowledge broadly throughout the organization and by acting in a coordinated manner" [25] (p. 1003). Both $\mathrm{MO}$ approaches have had great importance in understanding how market-oriented knowledge can contribute to innovations that influence performance. In particular, their studies have contributed to understanding the importance of building internal innovative capabilities, such as organizational innovativeness that utilize market knowledge as the main foundation to strategically meet and exceed customer needs on the market.

This study is based on Kohli and Jaworski's intelligence perspective on market orientation, paying special attention to how this framework influences the PHCs' customer responsiveness and strategic performance. Kohli and Jaworski's approach reveals the MO implementation process and its responsiveness effect on market needs [2]. Their focus is on company-wide knowledge development, starting with the gathering and dissemination of market information and ending in responsiveness based on acquired knowledge. The determination of whether responsiveness contributes to short-term or long-term effects requires that the concept be measured in relation to performance. If organizations gather information about market needs and circumstantial conditions affecting customer-buying decisions [26,27], then this accumulated knowledge base can enhance company responsiveness and business performance $[19,24]$.

Companies that seriously and effectively spread knowledge about the market as an intellectual mind-set [2] could more easily exceed customer expectations [26], especially if MO organizations integrate market knowledge as an intellectual mind-set in all functions throughout the organization [28]. Responsive actions help the company to strategically adjust their offerings, the products, and technology that contribute to performance. Responsiveness demonstrates willingness to meet market demands [27-29], showing the company's future orientation [2,28]. A quick response capability enables the company to assess its current knowledge and resources, provides direction for anticipating future knowledge, and creates the opportunity to reform processes supporting innovative ideas [18]. Chang et al. state that a company's responsiveness indicates its ability to react to market signals [30].

The PHC research emphasizes the importance of developing long-term plans to respond to current and future customers' needs [31]. Construction strategies (strategic performance/SP) can work as indicators for measuring nonfinancial performance [32], which can help companies establish a competitive position in the market built on responsiveness to customer demands. Construction strategies and investments signal the attractiveness of a place and the welfare offered in living conditions. Negative trends can be transformed into opportunities by applying MO as a basis for investment strategies. This approach goes beyond the previous government-ruled price-adjustment mechanism [31]. Based on the discussion above, the gathered and disseminated information and responsiveness (GDI/R) and MO/SP relationships lead to the following hypothesis:

H1. Market information knowledge affects the company responsiveness (GDI/R) relationship.

H1a. The MO and GDI/R relationship influence on strategic performance (MO/SP) relationship.

\subsection{The Mediating Role of CSR on the MO Responsiveness and Performance Relationship}

$\mathrm{MO}$ researchers disagree regarding the interconnectedness between $\mathrm{MO}$ and $\mathrm{SP}$, indicating that moderating and mediating effects can influence the relationship [18,26]. The question involves the extent to which different moderating (i.e., market turbulence, competitive environment) and mediating (i.e., internal ability and knowledge) elements influence the MO/SP relationship [7]. Mediating effects commonly relate to the internal work of an organization (i.e., human resources and knowledge implementation issues) and intervene in the relationship [33]. Table 1 shows how different studies have approached the CSR, MO, and performance relationship. 
Table 1. The CSR, MO, and performance relationship.

\begin{tabular}{|c|c|c|}
\hline Author/s & CSR, MO, and performance relationship & Result \\
\hline [34] & $\begin{array}{l}\text { MO (Kohli and Jaworski), CSR (aggregated) and } \\
\text { effects on organizational performance (not defined). }\end{array}$ & $\begin{array}{l}\text { CSR has a mediating influence on market } \\
\text { orientation and organizational performance. }\end{array}$ \\
\hline [19] & $\begin{array}{l}\text { MO (Narver and Slater), CSR (aggregated) and } \\
\text { effects on financial performance, corporate } \\
\text { reputation, employee commitment. }\end{array}$ & $\begin{array}{c}\text { CSR as moderator has synergistic influence on } \\
\text { the market orientation and business performance } \\
\text { relationship. }\end{array}$ \\
\hline [35] & $\begin{array}{c}\text { MO (Narver and Slater), innovation, and CSR } \\
\text { (aggregated) impact on business performance } \\
\text { (not defined). }\end{array}$ & $\begin{array}{l}\text { MO and CSR, as mediators, have significant } \\
\text { effects on innovation and then business } \\
\text { performance. MO has a direct effect on CSR. }\end{array}$ \\
\hline [36] & $\begin{array}{l}\text { MO (Slater and Narver), CSR (aggregated) and } \\
\text { customer satisfaction and the effects on } \\
\text { organizational performance }\end{array}$ & $\begin{array}{l}\text { CSR and customer satisfaction mediate the } \\
\text { MO-organizational performance relationship. }\end{array}$ \\
\hline [37] & $\begin{array}{c}\text { MO (Narver and Slater) aggregated) positive } \\
\text { influence on CSR (aggregated) and on stakeholders. } \\
\text { This relationship has effects on nonfinancial } \\
\text { organizational performance. }\end{array}$ & $\begin{array}{c}\text { MO has positive influence on CSR activities of } \\
\text { the firm. }\end{array}$ \\
\hline [38] & $\begin{array}{l}\text { CSR (aggregated) influence on MO (Narver and } \\
\text { Slater) constructs. }\end{array}$ & $\begin{array}{l}\text { Customer, competitive and inter-functional } \\
\text { orientation have significant influence on CSR. }\end{array}$ \\
\hline [39] & $\begin{array}{l}\text { MO constructs (Kohli and Jaworski), } \\
\text { sustainability/CSR (aggregated) and effects on firm } \\
\text { performance (shipping). }\end{array}$ & $\begin{array}{l}\text { Sustainability-influenced MO has a positive } \\
\text { impact on shipping performance. }\end{array}$ \\
\hline
\end{tabular}

The table shows that researchers have been strongly inspired by the works of Narver and Slater or Kohli and Jaworski (both are mentioned in the texts). CSR is used as an aggregated concept where the effects of the different dimensions (social, ecological, and economic) on MO constructs are not analyzed separately. Furthermore, the focus on performance varies considerably, which indicates that the measurements are made against different sources and difficult to compare. The table shows that views differ as to whether CSR should be seen as mediating the MO-SP relationship or having a moderating effect. None of the studies, except Pantouvakis et al. [39], has tested the effect of CSR on different MO constructs or tested how different CSR dimensions affect different MO constructs, which this article aims to do (gathering of information, dissemination, and responsiveness $=$ GDI $+\mathrm{R}$ ). However, there is a strong agreement that CSR has a positive influence on the strategic performance measured.

The CSR concept, like MO, is generic in terms of applicability to different organizations. Thus, CSR needs to be defined in the context and specific circumstances under investigation. Even though most research has emphasized how larger corporations make major investments in implementing a serious, business-integrated CSR agenda [40], it has become increasingly important for SMEs to engage as responsible business partners as well [12,41]. Another driving force, according to Freeman [13], is the inclusion of CSR relative to their interrelationship to critical stakeholders, which requires companies to take extended responsibility for environmental, social, and economic issues. There are "numerous applications of the stakeholder concept in the areas of ethics and social responsibility as they pertain to marketing" [13] (p. 156). Maignan et al. focus on CSR in relation to customers and consumers in society, because it affects the reputation of the company, which influences corporate performance [42].

CSR as integrated into core business activities is considered beneficial for business performance, because responsible actions change company behavior and culture, providing opportunities to bind the company functions together [43]. When incorporating CSR into their activities, companies experience "a clearer responsibility, more profound self-interest and greater potential" to become key actors on responsibility issues [12]. Since serious CSR response can improve image and reputation, increase shareholder value, attract talented candidates, and increase staff motivation [44], these efforts can contribute to improved business performance. From the above arguments, the following hypothesis is formed:

H2. CSR engagement has a positive influence on the company market knowledge and responsiveness (GDI/R) relationship.

H2a. CSR engagement positive influence on GDI/R relationship has influences the MO/SP relationship. 


\subsection{CSR's Mediating Influence on the MO Responsiveness and Performance Relationship}

Despite several beneficial arguments for implementing CSR, researchers debate whether the concept is normatively good and how well companies apply it in practice [45]. The voluntary nature of CSR adds to the debate over whether company engagement is based on genuine ethical and social legitimacy concerns [46], or purely driven by profit motives [47,48]. Concentrating on the legitimacy criterion, Sundström found that corporate engagement in CSR differs depending on situational aspects and the need for legitimacy linked to the business context [12]. A company that needs critical stakeholders' acceptance increases its CSR responsiveness, especially if the stakeholder is of economic importance. Sundström found that stakeholder requirements judged as being of less economic importance are commonly ignored, even when previously considered important [12]. This implies both that key stakeholders persuade companies to initiate the process but also that stakeholder importance might change over time. These findings support Mitchell et al.'s conclusion that business responsiveness to CSR demands depends on stakeholder urgency, legitimacy, and power [49].

Besides legitimacy reasons, one other main obstacle influencing CSR measures is company prioritization of issues [50]. Companies focus on certain types of responsibility more [51], so certain CSR dimensions (social, economic, and environmental) are regarded as more important to implement than others. In contrast to many studies that bundle different CSR dimensions together, this study analyzes how PHCs relate to the different dimensions of CSR to compare their different degrees of importance to $\mathrm{MO}$ responsiveness and strategic performance.

\subsubsection{The Social Relationship to MO Responsiveness and Performance}

Social responsibility has received only limited attention in research, both generally and in MO studies. Several studies mention how researchers take less interest in social than ecological responsibility [7,9] but do not pursue what this means, nor how it can be managed or analyzed. In particular, few attempts have been made to discuss how the social dimension of CSR could be related to the MO context. Nevertheless, researchers appear to agree that social responsibility concerns responsiveness related to human well-being, including issues of gender equality, diversity, corporate actions, and responsibility for the work environment, as well as contributions to communities generally [19] and to specific stakeholders directly affected by business activities [13]. These social responsibility concerns apparently affect customer satisfaction, employee motivation at work, and the attraction of a skilled workforce, which together enable the company to develop innovative capabilities [10]. Company responsiveness to CSR gives a human face to the organization that enhances customer perception of the company [19]. According to Brik et al., these perceptions positively influence business performance [19], leading to the following hypothesis:

H3. Social responsibility positively influences the GDI/R relationship.

H3a. Social responsibility positive influences on GDI/relationship has influence on the MO/SP relationship.

\subsubsection{The Economic Relationship to MO Responsiveness and Performance}

The economic dimension of CSR has received the least interest from researchers and is thus the most difficult to define. Essentially, economic responsibility touches on issues that also concern the social and ecological dimensions of CSR (e.g., circular economy, risk management in human resources). More specifically, economic responsibility issues have affected companies' risk management [17] and have been discussed in terms of corruption, fair business in relation to stakeholders, and the costs of working unsustainably. The economic perspective has also been influenced by Friedman's argument that "the business of business is business" [47], claiming that the only social responsibility companies have is to make a profit. By making a profit, companies can improve economic conditions, building up the structure and welfare of society. 
With the recent restructuring of companies with an impact on society, this relationship between profit and societal welfare can no longer be taken for granted [12]. Business is to be conducted ethically and morally defensibly, and in ways that contribute to societal benefits while improving company performance $[13,49,52]$. Economic responsibility and responsiveness to stakeholder demands help companies to create value related to the company by lowering financial costs and to be accountable to their stakeholders [17]. Risk management that promotes good economic and financial reputation creates trust among stakeholders and society, having an impact on performance. This leads to the following hypothesis:

H4. Economic responsibility positively influences the GDI/R relationship, which influences the MO/SP relationship.

H4a. Economic responsibility positive influences on GDI/relationship has influence on the MO/SP relationship.

\subsubsection{The Environmental Relationship to MO Responsiveness and Performance}

Research related to environmental responsibility has received the most attention in both CSR and sustainability research. With increased awareness of environmental problems, many researchers are seeking urgent solutions to this CSR dimension [53]. From an MO perspective, companies commonly pay attention to customer value of environmentally friendly goods and services [53]. Research within this dimension is often discussed in terms of how companies engage in strategic green action. These strategies are seen as an integral part of business activities, which also affect strategic performance. Eco-effective strategies that affect business performance have an encouraging impact on companies seeking new, improved ways to manage and find solutions to reuse scarce resources [54].

Environment-related activities are reported and measured to show how companies work with their environmental footprint and how they help to reduce the negative impact on the environment [54]. A company that exhibits low responsiveness to the interests of stakeholders risks being accused of greenwashing, which may lead to a negative impact on corporate performance. From this, the following hypothesis is formed:

H5. Environmental responsibility positively influences the GDI/R relationship, which influences the MO/SP relationship.

H5a. Environmental responsibility positive influences on GDI/relationship has influence on the MO/SP relationship.

\subsection{Strategic Performance}

In recent years researchers have noticed how construction strategies can increase profits in housing companies by increasing rent in new construction, reconstruction, and renovation [55,56]. Demolition and choice of vacancy rate are strategically used in most PHCs to equalize supply and demand for accommodation, but also to reduce costs at low demand, in turn leading to profits [57]. To understand and analyze strategic performance [26,58], we apply the concept of construction strategies that are assumed to have effects on financial performance.

Strategic performance (in this study, construction strategies) can be divided into distinct groups (such as new construction, renovation and reconstruction, demolition, vacancy, buying, and selling) to reach the goals of study [59]. Balancing short- and long-term strategies, financial and nonfinancial measures, and external and internal factors is seen as a complex company challenge when managing and measuring outcomes in a company [59-62]. Kaplan notices difficulties in planning for future strategic performance on the sole basis of measuring current financial outcomes [58]. Many companies attempt to achieve the right balance of performance strategies by reducing costs, trying to deliver appropriate products/services, and working with customer and employee satisfaction in order to create superior value [58]. Although the PHCs face different contextual conditions to meet the demands 
placed on them on the market, they are governed by the same real estate principles and the same law as private companies.

\section{Method}

The study tests how CSR influences (1) the gathered and disseminated market knowledge (GDI) and responsiveness (R) relationship, and (2) the $\mathrm{MO}(\mathrm{GDI}$ and $\mathrm{R}$ ) and strategic performance relationship (see Figure 1).

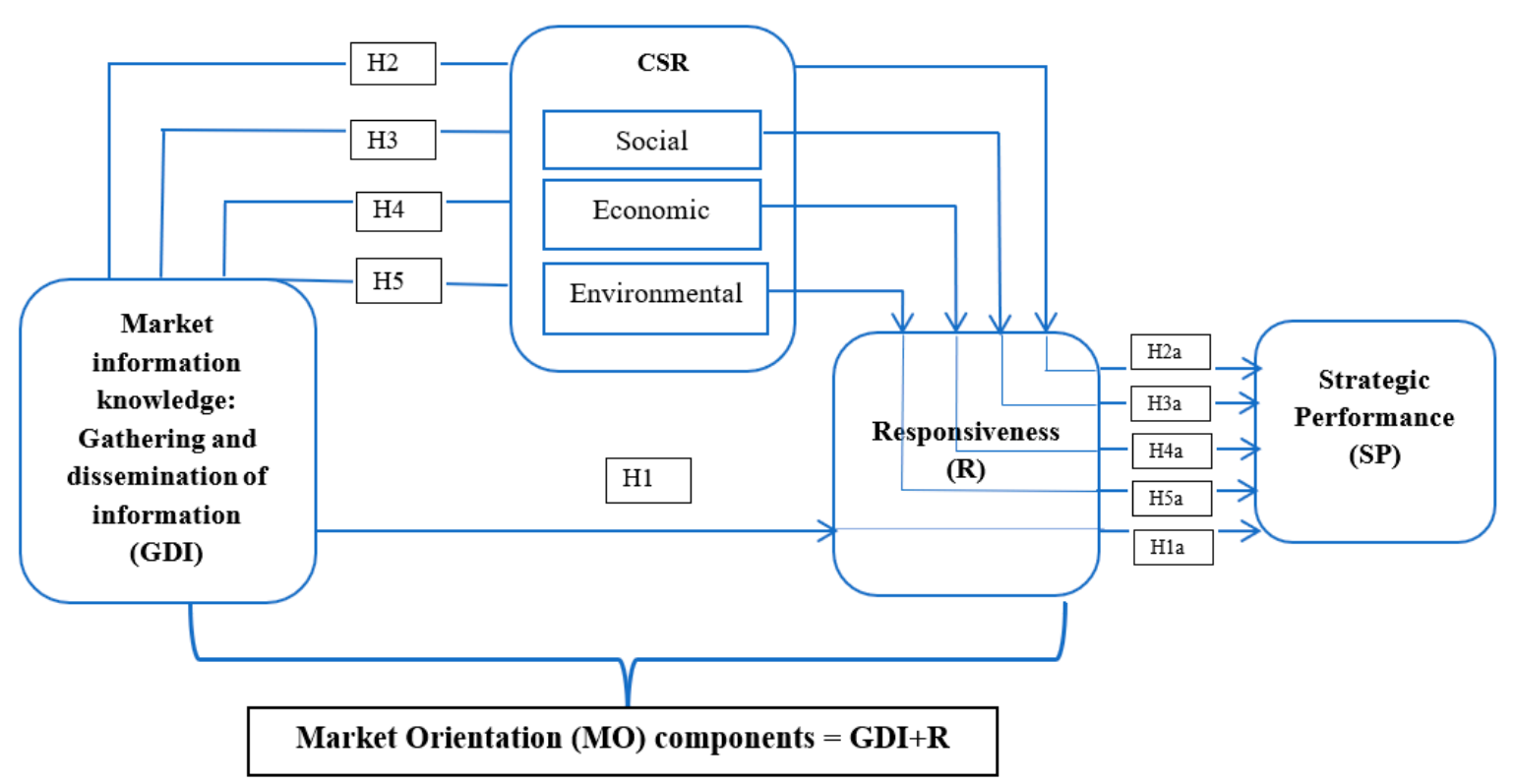

Figure 1. The mediating effects of CSR on the market orientation and strategic performance relationship.

\subsection{Survey Development}

Data was collected via a survey with questions based on previous MO research [2,29]. The survey was divided into four sections, with questions about (1) demographics, (2) the companies' gathering and dissemination of information, and responsiveness, (3) questions related to strategic performance (new construction, reconstruction, renovation, demolition of dwellings, vacancy, selling, and buying of housing) for the previous five years (2011-2015) and planned for the coming five years (2016-2020), and (4) mediating CSR questions related to social, environmental, and economic responsibilities.

The strategic performance questions in the third section were used to measure how the PHCs respond to the customers' needs concerning living conditions. Information about new construction and reconstruction shows the companies' long-term investment strategies requiring depreciation, whereas renovations are gradually performed and depreciated directly. Vacancies and demolition provide information about the level of attractiveness to customers. High levels of vacant apartments and a high demolition rate indicate that PHCs have a low demand for their products yet respond to a lack of customer need. The questions in the second to fourth sections were measured using a Likert scale from 1 to 7 , ranging from "strongly disagree" to "strongly agree."

The MO and CSR variables were controlled to ensure the significance of the study [63]. The 49 survey questions are based on the MARKOR survey developed by Kohli et al. [29] but adjusted to fit the specific PHC context and to include CSR questions. This adjustment provided both relevance to CSR and a limitation that lowers the comparability to other studies. To reduce response bias, difficult words that could cause confusion were avoided. The survey was double-checked by two experts to test and remove the least relevant questions, suggest additional items, and improve wording. 


\subsection{Sampling and Data Collection}

The PHCs were selected for their powerful situation in Sweden where they have an influence on regulations, as well as the legal and social issues of the rental market. Following a total analysis approach, all 289 PHCs in Sweden were included. The respondents have leading positions with knowledge of MO, CSR, and strategic performance. Before designing the survey, the researchers conducted four interviews with SABO and the Union of Tenants to improve knowledge of the PHC situation and to get advice on how to encourage answers to the survey.

Secondary data were collected from each PHC's website. SABO classifies PHCs into two main groups [64], declining and growing, depending on market size, population, and yearly turnover. The selected companies represent both declining and growing markets to provide an overall picture of how CSR influences the MO/SP relationship.

The data was collected via a multistep approach. The survey was first sent by email to 289 PHCs and made available for 90 days; 32 responses were received. After four follow-up reminders to increase response rate, an additional 133 responses were received, for 165 responses in total. Following the recommendation of Kumar et al. [28], the CEOs who initially did not respond were contacted to arrange personal interviews, which caused them to respond to the survey instead. All 165 PHCs responses are valid, since they represent a 57\% response rate. Compared to other MO studies, the response rate is satisfying. For instance, Hult et al. had a 19\% response rate [65].

The companies were grouped into three groups-declining, middle, and growing markets-according to standards that SABO and Boverket have for different types of PHCs $[64,66]$, to be sure the data were adequate and representative for each group. There, data were grouped depending on their turnover, population, and criteria on the Boverket and SABO websites. The reason for dividing the data was to be sure that there would be a sample of companies in each group adequate to calculate and measure different dimensions in the study. The pretest showed no significant differences in data regarding PHCs in terms of the different criteria of Boverket, which meant that they were treated as homogeneous groups for measurement.

Whenever a researcher categorizes data, there is risk of bias; misinterpretation of data might transfer into the analysis and influence the results. But the coding and categorizing of data were defined systematically in a theoretical, secured way by applying $\mathrm{MO}[2,4]$ and definition and categorization values as purposeful or recognized actions, which contributed to a high degree of reliability. The data was collected via a survey that was answered by PHCs. The answers from early versus late respondents were tested and found to have no effect on the study.

\subsection{Measurement, Reliability, and Validity}

The data was analyzed by factor and regression analysis [3]. Statistical internal reliability methods $[63,67]$ are combined by measuring correlations and Cronbach's alpha, and they show the linear relationship between two tested variables [63]. The Process analysis demonstrates how a variable's effect on an outcome can be partitioned into direct and indirect effects, which are easily quantified using OLS regression analysis [67]. Since in this study we want to measure the effect of direct and indirect variables, PROCESS analysis can be a good tool for analyzing data.

Factor analysis was used to estimate relationships between different dependent variables to measure if underlying factors can affect them. Table 2 reports factor loading and Cronbach's alpha measures for the reliability estimates for all variables in the study. The reliability of all scales is satisfactory, with $\alpha$ scores ranging from 0.60 to 0.90 . To examine for nonresponse bias, the researchers compared the declining and growing markets of the sampling frame. The two construction strategy variables "buying" and "demolition" were removed due to low Cronbach's alpha. Their composition was $47 \%$ and $53 \%$, respectively, indicating no significant difference. The average size of responding and nonresponding PHCs was compared by correlation analysis and shown to be significant. 
Table 2. Measurements of Factors and Variables.

\begin{tabular}{|c|c|c|}
\hline Factors and variables & Factor loading & Cronbach's Alpha \\
\hline Gathering Information a & & 0.721 \\
\hline We collect information about customers and their needs through informal methods. & 0.470 & \\
\hline We collect information about customers through formal methods (surveys/year). & 0.595 & \\
\hline We collect information about customer preferences through online comments. & 0.565 & \\
\hline We do customer surveys by survey once a year to measure customer satisfaction. & 0.565 & \\
\hline Dissemination of Information a & & 0.732 \\
\hline $\begin{array}{l}\text { When something important happens in the market, we inform everyone in the } \\
\text { company. }\end{array}$ & 0.671 & \\
\hline We have regular internal meetings where we discuss changes in the market. & 0.412 & \\
\hline We have regular meetings with the municipality about its development. & 0.687 & \\
\hline Responsiveness a & & 0.822 \\
\hline We respond rapidly to changes in the competition. & 0.780 & \\
\hline We rapidly identify changes in customer requirements. & 0.827 & \\
\hline We quickly discover technological developments for customers. & 0.729 & \\
\hline Economic ${ }^{a}$ & & 0.620 \\
\hline $\begin{array}{l}\text { We work actively to meet the customers' financial situation when we carry out } \\
\text { development work. }\end{array}$ & 0.681 & \\
\hline We always take into account the tenants' economic conditions for new construction. & 0.793 & \\
\hline Tenants are continually invited to information meetings to discuss economic issues. & 0.324 & \\
\hline Social a & & 0.723 \\
\hline We always take into consideration the tenants' social needs in change work. & 0.545 & \\
\hline $\begin{array}{l}\text { We invite tenants to participate in various social projects (neighborhood/leisure } \\
\text { activities). }\end{array}$ & 0.560 & \\
\hline We are actively working to handle social problems with tenants. & 0.575 & \\
\hline $\begin{array}{l}\text { Our code of conduct is used to regulate how we relate to social, environmental and } \\
\text { economic issues. }\end{array}$ & 0.572 & \\
\hline Environmental a & & 0.808 \\
\hline $\begin{array}{l}\text { We always take into account the environmental requirements in fulfilling the } \\
\text { housing requirements. }\end{array}$ & 0.726 & \\
\hline We invite tenants to participate in various environmental projects. & 0.588 & \\
\hline $\begin{array}{l}\text { We continuously follow the environmental requirements for existing and new } \\
\text { dwellings. }\end{array}$ & 0.640 & \\
\hline $\begin{array}{l}\text { We are actively working to find climate-friendly solutions for tenants (e.g., energy } \\
\text { efficiency, climate-smart houses, Kombo houses). }\end{array}$ & 0.690 & \\
\hline New construction (Strategic performance) ${ }^{b}$ & & 0.819 \\
\hline$(2011-2015)$ & 0.772 & \\
\hline$(2016-2020)$ & 0.775 & \\
\hline Reconstruction ${ }^{b}$ & & 0.892 \\
\hline$(2011-2015)$ & 0.732 & \\
\hline$(2016-2020)$ & 0.703 & \\
\hline Renovation/maintenance ${ }^{b}$ & & 0.824 \\
\hline$(2011-2015)$ & 0.841 & \\
\hline$(2016-2020)$ & 0.817 & \\
\hline Vacancy ${ }^{b}$ & & 0.811 \\
\hline$(2011-2015)$ & 0.912 & \\
\hline$(2016-2020)$ & 0.829 & \\
\hline Sale of housing ${ }^{b}$ & & 0.683 \\
\hline$(2011-2015)$ & 0.427 & \\
\hline (2016-2020) & 0.463 & \\
\hline
\end{tabular}

${ }^{\mathrm{a}}$ Measured on a 7-point scale $(1=$ strongly disagree, $7=$ strongly agree $) .{ }^{\mathrm{b}}$ Measured on a 7 -point scale $(1=$ nothing, $7=$ more than 500$)$.

CEOs were chosen as respondents for their presumed greater familiarity with this information and because in PHCs much of this information is limited to top management. CEOs are arguably the preferred respondent for measures of $\mathrm{MO}$ for their knowledge of external, market-related, and internal conditions.

The analysis of the study was based on literature review, and data were collected via a questionnaire with questions based on previous $\mathrm{MO}$ and real estate research [1,2]. A modified Kohli et al. [29] MARKOR scale was employed. To improve the reliability of the study, the questions were linked to the specific conditions in the context of PHCs in Sweden. When preparing and analyzing the interviews with PHCs, the market intelligence approach [2] was judged as more appropriate given the topic of investigation. Before distributing the final survey, pretest statistics and pilot tests were conducted to improve the face and content validity of the survey.

Content validity assessment for the initial version of the survey was performed using a two-step process. The first step involved asking a marketing expert, the second step involved a real estate 
expert to review the survey and ensure the items were an adequate and thorough representation of the constructs under investigation.

Table 3 shows means, standard deviations, and correlation coefficients. To assess the relationship between different items and ensure the validity of the multi-item measures, the researchers performed a correlation analysis.

Table 3. Descriptive and Correlation Analyses.

\begin{tabular}{|c|c|c|c|c|c|c|c|c|c|c|c|c|c|c|}
\hline & Variables & Mean & $\begin{array}{c}\text { Std. } \\
\text { Deviation }\end{array}$ & 1 & 2 & 3 & 4 & 5 & 6 & 7 & 8 & 9 & 10 & 11 \\
\hline 1 & $\begin{array}{l}\text { Gathering } \\
\text { Information }\end{array}$ & 4.53 & 1.364 & 1 & & & & & & & & & & \\
\hline 2 & $\begin{array}{l}\text { Dissemination of } \\
\text { Information }\end{array}$ & 5.39 & 1.098 & $0.392 * *$ & 1 & & & & & & & & & \\
\hline 3 & Responsiveness & 4.53 & 1.089 & $0.232 * *$ & $0.374 * *$ & 1 & & & & & & & & \\
\hline 4 & Economic (CSR) & 4.51 & 1.215 & $0.233^{* *}$ & 0.274 ** & $0.380 * *$ & 1 & & & & & & & \\
\hline 5 & Social (CSR) & 4.83 & 1.266 & $0.539 * *$ & 0.329 ** & $0.309 * *$ & $0.499 * *$ & 1 & & & & & & \\
\hline 6 & $\begin{array}{l}\text { Environmental } \\
\text { (CSR) }\end{array}$ & 5.28 & 1.253 & $0.509^{* *}$ & $0.366^{* *}$ & $0.343 * *$ & $0.441^{* *}$ & $0.703^{* *}$ & 1 & & & & & \\
\hline 7 & New construction & 2.99 & 1.594 & $0.345^{* *}$ & -0.090 & -0.018 & 0.045 & $0.335^{* *}$ & $0.300 * *$ & 1 & & & & \\
\hline 8 & Reconstruction & 2.39 & 1.462 & $0.299 * *$ & 0.016 & -0.078 & -0.013 & 0.235 ** & $0.298 * *$ & $0.629 * *$ & 1 & & & \\
\hline 9 & Renovation & 3.51 & 1.687 & $0.377^{* *}$ & -0.065 & -0.064 & 0.034 & $0.224 * *$ & $0.235 * *$ & $0.691 * *$ & $0.598 * *$ & 1 & & \\
\hline 10 & Vacancy & 1.36 & 0.453 & -0.096 & -0.035 & -0.116 & -0.018 & -0.183 * & -0.127 & $-0.276^{* *}$ & 0.014 & -0.059 & 1 & \\
\hline 11 & Sale & 1.80 & 1.259 & $0.166 *$ & -0.089 & $-0.186 *$ & -0.052 & $0.192 *$ & $0.212 * *$ & $0.516 * *$ & $0.444 * *$ & $0.369 * *$ & 0.064 & 1 \\
\hline
\end{tabular}

${ }^{*}$ Correlation is significant at the 0.05 level (2-tailed). ${ }^{* *}$ Correlation is significant at the 0.01 level (2-tailed).

\section{Results}

\subsection{Mediation Analyses}

The Process analysis for SPSS [67] was applied to measure the mediating CSR effect on (1) the $\mathrm{MO} / \mathrm{SP}$ relationship and (2) the gathering and dissemination of information and responsiveness (GDI/R) relationship. The significance of the indirect effects of CSR is calculated as a mediator [67], which provides a good bootstrap test. It enables the estimation of a multiple mediator model with the inclusion of multiple independent variables. This allowed testing of the mediation effects of CSR dimensions (multiple mediators) on both the GDI/R (independent MO variables) relationship and the MO (independent variables) and company SP (dependent variable) relationship. The significance level for the bias-corrected confidence interval was $95 \%$.

\subsection{Results of Hypothesis Testing of the MO and SP Relationship}

$\mathrm{H} 1$ and H1a suggested a positive effect between market knowledge (GDI), responsiveness (R), and strategic performance (SP). A positive relationship exists between GDI/R and the H1 hypothesis, with $\beta=0.338, p<0.001$. This shows that a positive effect exists between the different $M O$ variables.

$\mathrm{H} 1$ also suggests a positive MO/SP relationship, which is partly supported. The measurement indicates a negative but significant $\mathrm{MO} / \mathrm{SP}$ relationship related to reconstruction $(\beta=-0.176, p<0.010)$, renovation $(\beta=-0.167, p<0.010)$ and sale $(\beta=-0.242, p<0.010)$. This indicates that the PHCs work in a market-oriented way but with no effect on SP. The H1 is accepted relative to the GDI/R relationship (MO components), whereas the MO/SP relationship is not confirmed.

$\mathrm{H} 2$ and H2a suggested that CSR has a positive mediation effect on the GDI/R and MO/SP relationship. A positive total and indirect effect of GDI+CSR/R is supported. The analysis also shows a positive total effect $(\beta=0.348, p<0.001)$ and indirect effect $(\beta=0.180, p<0.001)$ of this relationship (see Tables 4 and 5). The measurement indicates that CSR has a mediating influence on the different $\mathrm{MO}$ components. When testing the effects of the MO+CSR/SP relationship, the total effect measurements are significantly related to new construction, reconstruction, and renovation. Table 5 shows the positive total effect for new construction $(\beta=0.298, p<0.005)$, reconstruction $(\beta=0.256, p<0.005)$, and renovation $(\beta=0.337, p<0.005)$. The measurement of indirect CSR effect is significant relative to new construction $(\beta=0.317, p<0.001)$, reconstruction $(\beta=0.205, p<0.010)$, and sale $(\beta=0.212, p<0.010)$, whereas with vacancy and renovation, the effect is not significant and not supported (see Table 5). This 
indicates that CSR has total effect, but no indirect effect on renovation. $\mathrm{H} 2$ is supported relative to $\mathrm{GDI}+\mathrm{CSR} / \mathrm{R}$ relationships (effects on $\mathrm{MO}$ components), but only supported for $\mathrm{MO}+\mathrm{CSR} / \mathrm{SP}$ when it comes to new construction, reconstruction, and sale. This indicates that CSR has effects on GDI/R (effects on $\mathrm{MO}$ ) and $\mathrm{MO} / \mathrm{SP}$ relationships, but not on vacancy and renovation.

Table 4. Process Analysis-The Mediating Effects of CSR on the GDI/R Relationship.

\begin{tabular}{|c|c|c|c|c|c|c|c|}
\hline \multirow{2}{*}{ Hypotheses } & & \multirow{2}{*}{$\frac{\text { Total effect }}{\beta}$} & \multirow{2}{*}{$\frac{\text { Direct effect }}{\beta}$} & \multicolumn{4}{|c|}{ Indirect effect } \\
\hline & & & & $\beta$ & Boot SE & LL 95\% & UL $95 \%$ \\
\hline H1: GDI/R & & $0.338^{* * *}$ & & & & & \\
\hline \multirow{2}{*}{ H2: GDI + CSR/R } & & $0.348^{* * *}$ & $0.168^{* * *}$ & $0.180^{* * *}$ & 0.060 & 0.075 & 0.317 \\
\hline & $\mathrm{R} 2$ & 0.114 & 0.180 & & & & \\
\hline \multirow[t]{2}{*}{ H3: GDI + Social/R } & & $0.348^{* * *}$ & $0.248^{* * *}$ & $0.100 * * *$ & 0.053 & 0.003 & 0.213 \\
\hline & $\mathrm{R} 2$ & 0.114 & 0.136 & & & & \\
\hline \multirow[t]{2}{*}{ H4: GDI + Economic/R } & & $0.348^{* * *}$ & $0.255^{* * *}$ & $0.093^{* * *}$ & 0.035 & 0.038 & 0.179 \\
\hline & $\mathrm{R} 2$ & 0.114 & 0.200 & & & & \\
\hline \multirow[t]{2}{*}{ H5: GDI + Environmental/R } & & $0.348^{* * *}$ & $0.223^{* * *}$ & $0.125^{* * *}$ & 0.056 & 0.023 & 0.244 \\
\hline & $\mathrm{R} 2$ & 0.114 & 0.150 & & & & \\
\hline
\end{tabular}

*** $p<0.001 .{ }^{* *} p<0.01 .{ }^{*} p<0.05$. Bootstrap 5000 .

Table 5. PROCESS Analysis-The Effects of CSR on the MO/SP Relationship.

\begin{tabular}{|c|c|c|c|c|c|}
\hline Hypotheses & New Construction & Reconstruction & Renovation & Vacancy & Sale \\
\hline H1a: MO/SP & -0.102 & $-0.175^{* *}$ & $-0.167^{* *}$ & -0.099 & $-0.242^{* *}$ \\
\hline \multicolumn{6}{|c|}{ H2a: $\mathrm{MO}+\mathrm{CSR} / \mathrm{SP}$} \\
\hline Total effect $\beta$ & $0.298 * *$ & $0.256^{* *}$ & $0.337^{* *}$ & -0.056 & 0.000 \\
\hline R 2 & 0.028 & 0.025 & 0.033 & 0.012 & 0.000 \\
\hline Direct effect $\beta$ & $-0.019^{* * *}$ & $0.051 * *$ & $0.157^{* *}$ & -0.021 & -0.212 ** \\
\hline $\mathrm{R} 2$ & 0.084 & 0.052 & 0.048 & 0.021 & 0.039 \\
\hline \multicolumn{6}{|l|}{ Indirect effect } \\
\hline Coefficient $\beta$ & $0.317 * * *$ & $0.205^{* *}$ & 0.180 & -0.035 & $0.212 * *$ \\
\hline Bootstrap SE & 0.104 & 0.083 & 0.107 & 0.029 & 0.085 \\
\hline LL 95\% & 0.135 & 0.062 & -0.023 & -0.097 & 0.066 \\
\hline UL 95\% & 0.553 & 0.394 & 0.409 & 0.020 & 0.409 \\
\hline \multicolumn{6}{|c|}{ H3a: MO + Social/SP } \\
\hline Total effect $\beta$ & $0.298 * *$ & $0.256^{*}$ & $0.337 *$ & -0.056 & 0.000 \\
\hline R 2 & 0.028 & 0.025 & 0.033 & 0.012 & 0.000 \\
\hline Direct effect $\beta$ & $-0.045 *$ & 0.064 * & 0.151 * & -0.008 & $-0.215^{* *}$ \\
\hline R 2 & 0.113 & 0.057 & 0.055 & 0.033 & 0.053 \\
\hline \multicolumn{6}{|l|}{ Indirect effect } \\
\hline Coefficient $\beta$ & $0.343^{* * *}$ & $0.192 * *$ & $0.186^{*}$ & -0.048 & $0.215^{* *}$ \\
\hline Bootstrap SE & 0.090 & 0.071 & 0.099 & 0.027 & 0.077 \\
\hline LL $95 \%$ & 0.192 & 0.075 & 0.001 & -0.105 & 0.094 \\
\hline UL 95\% & 0.546 & 0.357 & 0.396 & 0.002 & 0.411 \\
\hline \multicolumn{6}{|c|}{ H4a: $\mathrm{MO}+$ Economic/SP } \\
\hline Total effect $\beta$ & $0.298 * *$ & $0.256 * *$ & $0.337 * *$ & -0.056 & 0.000 \\
\hline R 2 & 0.028 & 0.025 & 0.033 & 0.120 & 0.000 \\
\hline Direct effect $\beta$ & $0.312 *$ & 0.307 * & $0.365 *$ & -0.062 & 0.032 \\
\hline R 2 & 0.029 & 0.031 & 0.034 & 0.013 & 0.003 \\
\hline \multicolumn{6}{|l|}{ Indirect effect } \\
\hline Coefficient $\beta$ & -0.014 & -0.052 & -0.028 & 0.005 & -0.032 \\
\hline Bootstrap SE & 0.053 & 0.051 & 0.061 & 0.014 & 0.045 \\
\hline LL 95\% & -0.123 & -0.167 & -0.164 & -0.024 & -0.122 \\
\hline UL 95\% & 0.091 & 0.035 & 0.076 & 0.033 & 0.057 \\
\hline \multicolumn{6}{|c|}{$\begin{array}{c}\text { H5a: } \mathrm{MO}+ \\
\text { Environmental/SP }\end{array}$} \\
\hline Total effect $\beta$ & 0.298 ** & $0.256^{* *}$ & $0.337^{* *}$ & -0.056 & 0.000 \\
\hline $\mathrm{R} 2$ & 0.028 & 0.025 & 0.033 & 0.012 & 0.000 \\
\hline Direct effect $\beta$ & $-0.000^{* * *}$ & $-0.024^{* * *}$ & $0.132 * * *$ & -0.030 & $-0.243^{* * *}$ \\
\hline $\mathrm{R} 2$ & 0.090 & 0.089 & 0.058 & 0.018 & 0.065 \\
\hline \multicolumn{6}{|l|}{ Indirect effect } \\
\hline Coefficient $\beta$ & $0.298^{* *}$ & $0.280 * *$ & $0.205^{* * *}$ & -0.026 & $0.243^{* * *}$ \\
\hline Bootstrap SE & 0.097 & 0.093 & 0.100 & 0.024 & 0.084 \\
\hline LL 95\% & 0.130 & 0.133 & 0.026 & 0.077 & 0.103 \\
\hline UL 95\% & 0.512 & 0.503 & 0.421 & 0.021 & 0.434 \\
\hline
\end{tabular}

${ }^{* * *} p<0.001 .{ }^{* *} p<0.01 .{ }^{*} p<0.05$. Bootstrap 5000. 
$\mathrm{H} 3$ and H3a suggested that the social dimension of CSR has a positive mediation effect on the GDI/R and MO/SP relationship. A positive total and indirect effect of GDI + Social/ $\mathrm{R}$ is supported. The analysis shows the positive total effect $(\beta=0.348, p<0.001)$ and indirect effect $(\beta=0.100, p<0.001)$ of this relationship (see Table 4). The measurement indicates that social responsibility affects the MO components. When testing the effects of the $\mathrm{MO}+$ Social/SP relationship, the total effect measurements are significant related to new construction, reconstruction, and renovation. Table 5 shows a positive total effect for new construction $(\beta=0.298, p<0.005)$, reconstruction $(\beta=0.256, p<0.010)$ and renovation $(\beta=0.337, p<0.010)$. As shown in Tables 4 and 5 , the indirect effect of social responsibility is significant for new construction $(\beta=0.343 p<0.001)$, reconstruction $(\beta=0.192, p<0.010)$, renovation ( $\beta=0.186, p<0.050)$ and sale $(\beta=0.215, p<0.010)$. The H3 GDI + Social/R relationship (effects on MO components) is supported when it comes to new construction, reconstruction, renovation, and sale but not vacancy.

$\mathrm{H} 4$ and H4a suggested that the economic dimension of CSR has a positive mediation effect on the GDI/R and MO/SP relationship. A positive total and indirect effect of GDI + Economic/R is supported. The analysis shows a positive total effect $(\beta=0.348, p<0.001)$ and indirect effect $(\beta=0.093$, $p<0.001$ ) of this relationship (see Table 4). The measurement indicates that the economic dimension of CSR affects the MO components. Testing the effects of the MO + Economic/SP relationship, the total effect is significant for new construction, reconstruction, and renovation. Table 5 shows a positive total effect for new construction $(\beta=0.298, p<0.005)$, reconstruction $(\beta=0.256, p<0.005)$, and renovation $(\beta=0.337, p<0.005)$. As shown in Table 5 , the indirect effect of CSR on SP is not significant with construction strategies (new construction, $\beta=-0.014 ; p>0.001$, reconstruction, $\beta=-0.052, p>0.001$; renovation, $\beta=-0.028, p>0.001$; vacancy, $\beta=0.005, p>0.001$; and sale $\beta=-0.032, p>0.001$ ) (see Table 5). H4 is supported relative to the GDI + Economic/R relationship, but not supported for the $\mathrm{MO}+$ Economic/SP relationship. This indicates that the economic dimension of CSR affects GDI/R (effects on $\mathrm{MO}$ ), but lacks indirect effect on $\mathrm{MO} / \mathrm{SP}$ relationships.

$\mathrm{H} 5$ and H5a suggested that the environmental dimension of CSR has a positive mediation effect on the GDI/R and MO/SP relationship. A positive total and indirect effect of GDI + Environmental/R is supported. The analysis shows a positive total effect $(\beta=0.348, p<0.001)$ and indirect effect $(\beta=0.125$, $p<0.001$ ) of this relationship (see Table 4). The measurement indicates that the environmental dimension of CSR affects the MO components. When testing the effects of the MO + Environmental/SP relationship, the total effect measurements are significant related to new construction, reconstruction, and renovation. Table 5 shows positive total effect for new construction $(\beta=0.298, p<0.005)$, reconstruction $(\beta=0.256, p<0.005)$, and renovation $(\beta=0.337, p<0.005)$. As shown in Table 5, the indirect effect is significant with new construction $\beta=0.298, p<0.005$, reconstruction $\beta=0.280$, $p<0.005$, renovation $\beta=0.205, p<0.001$, and sale $\beta=0.243, p<0.001$ (see Table 5).

$\mathrm{H} 4$ is supported for the GDI + Environmental/R relationship (effects on MO components) when it comes to new construction, reconstruction, renovation, and selling. This indicates that the environmental dimension has effects on the GDI/R (effects on MO) and MO/SP relationships but not on vacancy.

Since all of these effects are significant and the explanation of the independence variable increases from R2 (see Tables 4 and 5) in the partial mediation model, we can assume that CSR has a partial mediating effect on the relationship between $\mathrm{MO}$ and strategic performance.

\section{Discussion}

This study analyzed the mediating effects of CSR on the MO/SP relationship, as well as the CSR impact on PHC responsiveness to gathered and disseminated information (GDI) about the customers. The two measurements contribute to show whether PHCs' CSR commitments correspond to customers' shorter-term MO needs and if CSR has a long-term impact on MO related to construction strategies (see Table 6). Table 6 is a summary of the results of study; for more detail, see Tables 4 and 5. 
Table 6. The result of analysis for the hypotheses.

\begin{tabular}{ccc}
\hline Hypothesis & Description & Findings \\
\hline $\mathrm{H} 1$ & $\mathrm{MO} / \mathrm{SP}$ & Not supported \\
$\mathrm{H} 2$ & $\mathrm{MO}+\mathrm{CSR} / \mathrm{SP}$ & Supported \\
$\mathrm{H} 3$ & $\mathrm{MO}+$ Social/SP & Supported \\
$\mathrm{H} 4$ & $\mathrm{MO}+$ Economic/SP & Not supported \\
$\mathrm{H} 5$ & $\mathrm{MO}+$ Environmental/SP & Supported \\
\hline
\end{tabular}

To analyze the mediating role of CSR, the $\mathrm{MO} / \mathrm{R}$ and $\mathrm{MO} / \mathrm{SP}$ relationships were analyzed first. The MO intelligence perspective of Kohli and Jaworski [1,2] assumes a positive link exists between how companies gather information about customer needs, how they use and disseminate that information internally to build internal intelligence, and how they respond to customer needs. The study confirms the link between the GDI/R relationship (MO components), which indicates that PHCs work in a market-oriented fashion, whereas the long-term MO/SP link is not confirmed. This indicates that PHCs have developed knowledge about customer needs but do not use it when making decisions about construction strategies.

According to CSR research [42-44], substantial efforts can have a positive effect on a company's internal behavior and motivation, enabling improvements in reputation and business performance. The findings show that CSR has positive effects on the GDI/R (MO components) relationship but only partially relative to the $\mathrm{MO} / \mathrm{SP}$ relationships, because the vacancy and renovation strategies are not accepted. This means that CSR exerts a positive influence on PHCs' work with MO, but neither the market knowledge constructs nor customer responsibility affects their decisions on vacancies or renovation strategies.

Because CSR covers completely different dimensions of responsibility (social, economic and environmental), these can affect different parts of an organization in different ways. Research shows that many organizations find they must prioritize the CSR issues perceived as most relevant to their business activities [49,50]. For PHCs, all three CSR dimensions are of relevance. The issues of customer living conditions and their ability to negotiate and influence decisions through their membership in the Union of Tenants represent the social dimension. Environmentally, the PHCs are responsible for building materials and chemicals, etc., which affect the tenants' outside and inside living environments. And the companies' main mission is to serve groups with scarce economic resources, which is the economic dimension. Therefore, it is relevant to analyze and compare the CSR dimensions that affect the GDI/R and MO/SP relationship.

The study showed that the social dimension positively affects the GDI/R (MO) and the MO/SP relationships except on vacancy. This implies that the PHCs are working seriously on social issues that improve the working environment, which have a positive impact on their long-term relationship to customer needs and well-being related to construction strategies. The analysis of the economic dimension shows an effect on GDI/R but is not confirmed for the MO/SP relationship. PHCs take economic responsibility for customer issues relating to more short-term decisions, but not for their construction strategies. The analysis shows that the environmental dimension has the strongest effects on the GDI/R and $\mathrm{MO} / \mathrm{SP}$ relationships, save for vacancy. These findings confirm the massive interest in research to find urgent solutions to environmental problems [53]. MO research focuses on how environmentally friendly goods and services are valued by the customers, and how companies' green actions can affect strategic performance [53]. Eco-effective strategies encourage companies to seek new, environmentally friendly ways to find solutions to reuse scarce resources [54], which also affect business performance.

In summary, PHC works on a market-oriented basis, but with the exception of CSR, this work has no effect on decisions about construction strategies. All CSR dimensions have mediating effects on how PHC meets customer needs. However, the social and, above all, environmental dimensions have the greatest impact on PHCs' construction strategies. 


\section{Conclusion and Research Implications}

The results of the study confirm that it is not enough in research to focus solely on MO components and the impact of customer needs on strategic decisions. The study shows that CSR has a vital mediating role that forces PHCs to move beyond the customers' basic needs. Customers today are more discerning and require companies to act responsibly in ways that meet needs that are more sophisticated.

The result contributes to MO research by providing knowledge to reveal the workings of the "black box" addressed by Ellinger et al. [6]. CSR needs to be seen as an integral part of the company's MO work to develop and strategically utilize market knowledge more efficiently. The study shows that CSR has a positive impact on MO components and, above all, increases company responsiveness-even if this work only leads to more short-term commitments. Along with the positive relationship between MO components, CSR indirectly contributes to increasing this positive relationship, which improves the company's internal learning, abilities, and innovativeness.

Furthermore, the study contributes both to research and practice by showing the importance of determining which strategic performance to measure, as these provide different results, regardless of whether the relationships between $\mathrm{MO} / \mathrm{SP}$ or MO+CSR/SP are considered. The results also show that MO has no direct effect on new construction, but when including the mediation effects of CSR, this relationship was confirmed. Therefore, CSR can significantly improve a company's work with MO having effects on SP. The study shows that the MO-SP relationship is not confirmed, but if CSR is added as mediator, then the effects on the relationship is positive.

Interestingly, renovations, which are probably the most common strategy taken by PHCs today, were not affected by MO, nor by CSR involvement. According to SABO's website, many dwellings are in need of refurbishment whether, or not, there is current customer need for it. The study has several limitations that mainly deal with the methodological modifications required to suit the specific PHC conditions and CSR integration in the study. This implies that the Kohli et al. MARKOR model [29] could not be fully applied. This probably limits the replicability of the study to studies of construction strategies.

Author Contributions: Conceptualization, A.S.; methodology, Z.A. and A.S.; software, Z.A.; validation, Z.A. and A.S.; formal analysis, Z.A. and A.S.; investigation, A.S. and Z.A.; data curation, Z.A.; writing-original draft preparation, A.S.; writing—review and editing, A.S. and Z.A.; visualization, A.S.; project administration, A.S. and Z.A.

Funding: This research received no external funding.

Conflicts of Interest: The authors declare no conflict of interest.

\section{References}

1. Jaworski, J.; Kohli, A. Market Orientation: Antecedents and Consequences. J. Mark. 1993, 57, 53-70. [CrossRef]

2. Kohli, A.K.; Jaworski, B. Market Orientation: The Construct, Research Propositions, and Managerial Implications. J. Mark. 1990, 54, 1-18. [CrossRef]

3. Kirca, A.H.; Jayachandran, S.; Bearden, W.O. Market Orientation: A Meta-Analytic Review and Assessment of Its Antecedents and Impact on Performance. J. Mark. 2005, 69, 24-41. [CrossRef]

4. Narver, J.C.; Slater, S.F. The Effect of a Market Orientation on Business Profitability. J. Mark. 1990, 54, $20-35$. [CrossRef]

5. Foley, A.; Fahy, J. Seeing Market Orientation through a Capabilities Lens. Eur. J. Mark. 2009, 43, 13-20. [CrossRef]

6. Ellinger, A.E.; Ketchen, D.J.; Hult, G.T.; Elmadag, A.B.; Richey, R.G. Market Orientation, Employee Development Practices, and Performance in Logistics Service Provider Firms. Ind. Mark. Manag. 2008, 37, 353-366. [CrossRef]

7. Mitchell, R.W.; Wooliscroft, B.; Higham, J. Sustainable Market Orientation: A New Approach to Managing Marketing Strategy. J. Macromarket. 2010, 30, 160-170. [CrossRef] 
8. Kiessling, T.; Isaksson, L.; Yasar, B. Market Orientation and CSR: Performance Implications. J. Bus. Ethics 2016, 137, 269-284. [CrossRef]

9. Fatma, M.; Rahman, Z.; Khan, I. Building Company Reputation and Brand Equity through CSR: The Mediating Role of Trust. Int. J. Bank Market. 2015, 33, 840-856. [CrossRef]

10. Luo, X.; Bhattacharya, C.B. Corporate Social Responsibility, Customer Satisfaction, and Market Value. J. Mark. 2006, 70, 1-18. [CrossRef]

11. Sundström, A.; Ahmadi, Z.; Hyder, A.S. Market and Innovation Orientation Typology: Proposition and Illustrations. Mark. Intell. Plan. 2016, 34, 376-393. [CrossRef]

12. Sundström, A. Globalization, CSR and Business Legitimacy in Local Relationships. Ph.D. Thesis, Faculty of Natural Resources and Agricultural Sciences, SLU, Uppsala, Sweden, 2009.

13. Freeman, R.E. Response: Divergent Stakeholder Theory. Acad. Manag. Rev. 1999, 24, 233-236. [CrossRef]

14. Aras, G.; Crowther, D. The Durable Corporation: Strategies for Sustainable Development; Gower: Aldershot, UK, 2009; ISBN 978-05-6608-819-3.

15. Famiyeh, S. Corporate Social Responsibility and Firm's Performance: Empirical Evidence. Soc. Responsib. J. 2017, 13, 390-406. [CrossRef]

16. Quazi, A.; Richardson, A. Sources of Variation in Linking Corporate Social Responsibility and Financial Performance. Soc. Responsib. J. 2012, 8, 242-256. [CrossRef]

17. Magnanelli, S.; Izzo, M.F. Corporate Social Performance and Cost of Debt: The Relationship. Soc. Responsib. J. 2017, 13, 250-265. [CrossRef]

18. Kara, A.; Spillan, J.E.; Deshields, O.W. The Effect of a Market Orientation on Business Performance: A Study of Small-Sized Service Retailers Using MARKOR Scale. J. Small Bus. Manag. 2005, 43, 105-118. [CrossRef]

19. Brik, A.B.; Rettab, B.; Mellahi, K. Market Orientation, Corporate Social Responsibility, and Business Performance. J. Bus. Ethics 2011, 99, 307-324. [CrossRef]

20. Narver, J.C.; Slater, S.F.; MacLachlan, D.L. Responsive and Proactive Market Orientation and New-Product Success. J. Prod. Innov. Manag. 2004, 21, 334-347. [CrossRef]

21. Lind, H.; Lundström, S. Hur ett Affärsmässigt Bostadsföretag Agera; Division of Building and Real Estate Economics KTH: Stockholm, Sweden, 2011.

22. Lind, H. Rent Regulation and New Construction: With a Focus on Sweden 1995-2001. Swed. Econ. Policy Rev. 2003, 10, 135-167.

23. Doblhammer, G.; Van den Berg, G.J.; Fritze, T. Economic Conditions at the Time of Birth and Cognitive Abilities Late in Life: Evidence from Ten European Countries. PLoS ONE 2013, 8, e74915. [CrossRef] [PubMed]

24. Jaworski, J.; Kohli, A. Market Orientation: Review, Refinement, and Roadmap. J. Market-Focused Manag. 1996, 1, 119-135. [CrossRef]

25. Slater, S.; Narver, J. Customer-Led and Market-Oriented: Let's Not Confuse the Two. Strateg. Manag. J. 1998, 19, 1001-1006. [CrossRef]

26. Chung, J.-E.; Huang, Y.; Jin, B.; Sternquist, B. The Impact of Market Orientation on Chinese Retailers' Channel Relationships. J. Bus. Ind. Mark. 2011, 26, 14-25. [CrossRef]

27. Wang, C.H.; Chen, K.Y.; Chen, S.C. Total Quality Management, Market Orientation and Hotel Performance: The Moderating Effects of External Environmental Factors. Int. J. Hosp. Manag. 2012, 31, 119-129. [CrossRef]

28. Kumar, V.; Jones, E.; Venkatesan, R.; Leone, R. Is Market Orientation a Source of Sustainable Competitive Advantage or Simply the Cost of Competing? J. Mark. 2011, 75, 16-30. [CrossRef]

29. Kohli, A.K.; Jaworski, B.J.; Kumar, A. MARKOR: A Measure of Market Orientation. J. Mark. Res. 1993, 30, 467-477. [CrossRef]

30. Chang, S.; Gong, Y.; Way, S.A.; Jia, L. Flexibility-oriented HRM Systems, Absorptive Capacity, and Market Responsiveness and Firm Innovativeness. J. Manag. 2013, 39, 1924-1951. [CrossRef]

31. Jacobs, K.; Berry, M.; Dalton, T. A Dead and Broken System?: Insider Views of the Future Role of Australian Public Housing. Int. J. Hous. Policy 2013, 13, 173-201. [CrossRef]

32. Banker, R.D.; Potter, G.; Srinivasan, D. Association of Nonfinancial Performance Measures with the Financial Performance of a Lodging Chain. Cornell Hotel Restaur. Admin. Quart. 2005, 46, 394-412. [CrossRef]

33. Liao, S.-H.; Chang, W.-J.; Wu, C.-C.; Katrichis, J.M. A Survey of Market Orientation Research (1995-2008). Ind. Mark. Manag. 2011, 40, 301-310. [CrossRef] 
34. Qu, R. The Impact of Market Orientation and Corporate Social Responsibility on Firm Performance: Evidence from China. Asia Pac. J. Mark. Logist. 2009, 21, 570-582. [CrossRef]

35. Mahmoud, M.A.; Hinson, R.E. Market Orientation, Innovation and Corporate Social Responsibility Practices in Ghana's Telecommunication Sector. Soc. Responsib. J. 2012, 8, 327-346. [CrossRef]

36. Qu, R. Market Orientation and Organizational Performance Linkage in Chinese Hotels: The Mediating Roles of Corporate Social Responsibility and Customer Satisfaction. Asia Pac. J. Tour. Res. 2014, 19, 1399-1416. [CrossRef]

37. Felix, R. Market Orientation Plus: Antecedents and Consequences of Market Orientation and Corporate Social Responsibility in Mexico. J. Glob. Mark. 2015, 28, 172-188. [CrossRef]

38. Jebarajakirthy, C.; Thaichon, P.; Dhanushanthini, Y. Enhancing Corporate Social Responsibility through Market Orientation Practices in Bottom of Pyramid Markets: With Special Reference to Microcredit Institutions. J. Strateg. Mark. 2016, 24, 398-417. [CrossRef]

39. Pantouvakis, A.; Vlachos, I.; Zervopoulos, P.D. Market Orientation for Sustainable Performance and the Inverted-U Moderation of Firm Size: Evidence from the Greek Shipping Industry. J. Clean. Prod. 2017, 165, 705-720. [CrossRef]

40. Sen, S.; Bhattacharya, C.; Korschun, D. The Role of Corporate Social Responsibility in Strengthening Multiple Stakeholder Relationships. J. Acad. Mark. Sci. 2006, 34, 158-166. [CrossRef]

41. Ciliberti, F.; Pontrandolfo, P.; Scozzi, B. Investigating Corporate Social Responsibility in Supply Chains: A SME Perspective. J. Clean. Prod. 2008, 16, 1579-1588. [CrossRef]

42. Maignan, I.; Ferrell, O.C.; Ferrell, L. A Stakeholder Model for Implementing Social Responsibility in Marketing. Eur. J. Mark. 2005, 39, 956-977. [CrossRef]

43. Lindgreen, A.; Hingley, M.K.; Grant, D.B.; Morgan, R.E. Value in Business and Industrial Marketing: Past, Present, and Future. Ind. Mark. Manag. 2012, 41, 207-214. [CrossRef]

44. Riccò, R.; Guerci, M. Diversity Challenge: An Integrated Process to Bridge the Implementation Gap. Bus. Horiz. 2014, 57, 235-245. [CrossRef]

45. Bowen, F.; Cousins, P.; Lamming, R.; Faruk, A. The Role of Supply Management Capabilities in Green Supply. Prod. Oper. Manag. 2001, 10, 174-189. [CrossRef]

46. Carroll, A.B. A three-dimensional conceptual model of corporate social performance. Acad. Manag. Rev. 1979, 4, 497-505. [CrossRef]

47. Friedman, M. The Social Responsibility of Business Is to Increase Its Profits. New York Times Magazine, 13 September 1970.

48. Prahalad, C.K.; Hammond, A. Serving the World's Poor, Profitably. Harv. Bus. Rev. 2002, 80, 48-59.

49. Mitchell, R.; Agle, B.; Wood, D. Toward a Theory of Stakeholder Identification and Salience: Defining the Principle of Who and What Really Counts. Acad. Manag. Rev. 1997, 22, 853-886. [CrossRef]

50. Husted, B.W.; Allen, D.B. Allen Strategic Corporate Social Responsibility and Value Creation among Large Firms Lessons from the Spanish Experience. Long Range Plan. 2007, 40, 594-610. [CrossRef]

51. Cruz, J.M.; Wakolbinger, T. Multiperiod effects of corporate social responsibility on supply chain networks, transaction costs, emissions, and risk. Int. J. Prod. Econ. 2008, 116, 61-74. [CrossRef]

52. Donaldson, T.; Preston, L.E. The Stakeholder Theory of the Corporation: Concepts, Evidence, and Implications. Acad. Manag. Rev. 1995, 20, 65-91. [CrossRef]

53. Chen, Y.; Tang, G.; Jin, J.; Li, L.; Paillé, P. Linking Market Orientation and Environmental Performance: The Influence of Environmental Strategy, Employee's Environmental Involvement, and Environmental Product Quality. J. Bus. Ethics 2015, 127, 479-500. [CrossRef]

54. Feng, M.; Wang, X.; Kreuze, J.G. Corporate Social Responsibility and Firm Financial Performance. Am. J. Bus. 2017, 32, 106-133. [CrossRef]

55. Lind, H.; Borg, L. Service-led Construction: Is It Really the Future? Constr. Manag. Econ. 2010, 28, 1145-1153. [CrossRef]

56. Lind, H.; Annadotter, K.; Björk, F.; Högberg, L.; Af Klintberg, T. Sustainable Renovation Strategy in the Swedish Million Homes Programme: A Case Study. Sustainability 2016, 8, 388. [CrossRef]

57. Musterd, S. Public Housing for Whom? Experiences in an Era of Mature Neo-Liberalism: The Netherlands and Amsterdam. Hous. Stud. 2014, 29, 467-484. [CrossRef]

58. Kaplan, R.S. Strategic Performance Measurement and Management in Nonprofit Organizations. Nonprofit Manag. Leadersh. 2001, 11, 353-370. [CrossRef] 
59. Srivastava, A.K.; Sushil. Modeling Strategic Performance Factors for Effective Strategic Execution. Int. J. Prod. Perform. Manag. 2013, 62, 554-582. [CrossRef]

60. Kaplan, R.; Norton, D. Using the Balanced Scorecard as a Strategic Management System. Harv. Bus. Rev. 1996, 74, 75-85.

61. Kaplan, R.; Norton, D.P. The Office of Strategic Management. Strateg. Financ. 2005, 87, 56-60.

62. Rockart, J. Chief Executives Define Their Own Data Needs. Harv. Bus. Rev. 1979, 57, 81-93.

63. Hair, J.F.; Black, W.C.; Babin, B.J.; Anderson, R.E. Multivariate Data Analysis; Prentice Hall: Englewood Cliffs, NJ, USA, 2013.

64. SABO. Swedish Association of Public Housing Companies Home Page. Available online: http://www.sabo. se (accessed on 10 April 2016).

65. Hult, G.; Tomas, M.; Hurley, R.F.; Knight, G.A. Innovativeness: Its Antecedents and Impact on Business Performance. Ind. Mark. Manag. 2001, 33, 429-438. [CrossRef]

66. Boverket. Analys av Utvecklingen på Svaga Bostadsmarknader [Analysis of Development in Weak Housing Markets], Statens Bostadskreditnämnd Budgetunderlag 2012-2014. Available online: http: / www. boverket.se/globalassets / publikationer/dokument/2011/analys-svaga-bostadsmarknader.pdf (accessed on 15 October 2015).

67. Hayes, A.F. Introduction to Mediation, Moderation, and Conditional Process Analysis, a Regression-Based Approach; Guilford Press: New York, NY, USA, 2013.

(C) 2019 by the authors. Licensee MDPI, Basel, Switzerland. This article is an open access article distributed under the terms and conditions of the Creative Commons Attribution (CC BY) license (http://creativecommons.org/licenses/by/4.0/). 